\title{
Virological investigation of four outbreaks of influenza B reassortants in the northern region of Taiwan from October 2006 to February 2007
}

\author{
Yuan-Ming Lee ${ }^{1,2,3}$, Sheng-Fan Wang ${ }^{5}$, Cheng-Ming Lee ${ }^{4}$, Kuan-Hsuan Chen ${ }^{1}$, \\ Yu-Jiun Chan ${ }^{1,2,6}$, Wu-Tse Liu ${ }^{5}$ and Yi-Ming Arthur Chen*4,7
}

\begin{abstract}
Address: ${ }^{1}$ Institute of Public Health, School of Medicine, National Yang-Ming University, Taipei, Taiwan, ROC, ${ }^{2}$ Division of Clinical Virology, Department of Pathology and Laboratory Medicine, Taipei Veterans General Hospital, Taipei, Taiwan, ROC, ${ }^{3}$ Division of Laboratory Medicine, National Yang-Ming University Hospital, Yilan, Taiwan, ROC, ${ }^{4}$ AIDS Prevention and Research Center, National Yang-Ming University, Taipei, Taiwan, ROC, ${ }^{5}$ Institute of Medical Technology, National Yang-Ming University, Taipei, Taiwan, ROC, ${ }^{6}$ Division of Infectious Disease, Department of Medicine, Taipei Veterans General Hospital, Taipei, Taiwan, ROC and 'Department of Microbiology, School of Medicine, National Yang-Ming University, Taipei, Taiwan, ROC
\end{abstract}

Email: Yuan-Ming Lee -ymlee@vghtpe.gov.tw; Sheng-Fan Wang - goodmulder@yahoo.com.tw; Cheng-Ming Lee - d48907007@ym.edu.tw; Kuan-Hsuan Chen - g39607001@ym.edu.tw; Yu-Jiun Chan - yjchan@vghtpe.gov.tw; Wu-Tse Liu - wtliu@ym.edu.tw; YiMing Arthur Chen* - arthur@ym.edu.tw

* Corresponding author

\section{Published: 9 May 2009}

BMC Research Notes 2009, 2:86 doi:10.1 186/1756-0500-2-86
Received: 12 March 2009

Accepted: 9 May 2009

This article is available from: http://www.biomedcentral.com/I756-0500/2/86

(c) 2009 Chen et al; licensee BioMed Central Ltd.

This is an Open Access article distributed under the terms of the Creative Commons Attribution License (http://creativecommons.org/licenses/by/2.0), which permits unrestricted use, distribution, and reproduction in any medium, provided the original work is properly cited.

\begin{abstract}
Background: From October 2006 to February 2007, clinical specimens from 452 patients with symptoms related to respiratory tract infection in the northern region of Taiwan were collected. Real-time PCR and direct immunofluorescent antibody tests showed that $145(32 \%)$ patients had influenza $B$ virus infections. Subsequently, nucleotide sequence analyses of both hemagglutinin (HA) and neuraminidase (NA) genes of 39 isolates were performed. Isolated viruses were antigenically characterized using hemagglutinin inhibition $(\mathrm{HI})$ test.
\end{abstract}

Findings: Phylogenetic tree analysis showed that all the isolates belonged to the $B$ reassortant lineage with $\mathrm{HA}$ gene belonged to the $B /$ Victoria/2/87 lineage and the NA gene belonged to the $B /$ Yamagata/16/88 lineage. In addition, a group of children aged between 6 to 8 years old resided in Yilan county were infected with a variant strain. Hemagglutinin inhibition $(\mathrm{HI})$ tests confirmed that all the reassortant influenza B viruses were B/Malaysia/2506/04-like viruses. Pre- and postimmunized serum samples from 4 normal volunteers inoculated with 2007 influenza vaccine were evaluated for their $\mathrm{Hl}$ activity on 6 reassortant $\mathrm{B}$ isolates including two variants that we found in the Yilan county. The results demonstrated that after vaccination, all four vaccinees had at least 4fold increases of their $\mathrm{HI}$ titers.

Conclusion: The results indicate that the 2006-2007 seasonal influenza vaccine was effective in stimulating protective immunity against the influenza $B$ variants identified in Yilan county. Continuous surveillance of emerging influenza $B$ variants in the northern region of Taiwan is important for the selection of proper vaccine candidate in the future. 


\section{Background}

Enveloped orthomyxoviruses have segmented negativesense RNA genomes that facilitate new strain development via mutations and the reassortment of gene segments. This genetic instability is responsible for annual international epidemics and periodic pandemics of influenza infections $[1,2]$. Influenza viruses are spread by small airborne droplets expelled while talking, breathing, and coughing. The most susceptible population is children, and school-age children are the most common spreaders of infection [3-7]. Vaccines are thought to be the most effective modality for influenza control, and phylogenetic analyses of genes of viruses provide valuable information for vaccine development and prophylaxis.

Hemagglutinin (HA) and neuraminidase (NA) genes have been used to study influenza B virus evolution [8-10]. Two lineages have been identified as co-circulating since 1983: B/Victoria/2/87 (Vic87) and B/Yamagata/16/88 (Yam88) [11], and reassortants of the two lineages have been observed since 2002 [12-18]. The increasing appearance of reassortant influenza B was reported in Taiwan from 2002 to 2005 [19].

We conducted phylogenetic analyses of HA and NA genes from influenza B virus isolates collected from a group of children complaining of severe headaches in north Taiwan between October 2006 and February 2007. Variants were further tested using a hemagglutinin inhibition (HI) test with a panel of anti-flu B antisera; our results indicate incomplete inhibition. Data from an amino acid sequence analysis of the HA protein showed greater sequence variation to B/Malaysia/2506/04-like viruses in 5 influenza B variants (B/Taiwan/3009/06, B/Taiwan/3802/06, B/Taiwan/3804/06, B/Taiwan/3805/06, and B/Taiwan/3790/ $06)$.

\section{Methods Subjects}

Between October 2006 and February 2007, 452 throat swabs from patients with symptoms related to respiratory tract infection were collected at the clinical virology laboratory of the Taipei Veterans General Hospital. This laboratory has a contract with the Taiwan's Centers for Disease Control and is responsible for the virological evaluation of all the specimens sent from different hospitals in the northern region of Taiwan. The epidemiological curve and geographic distribution were shown in Figures 1 and 2 . The median age of 145 patients with influenza B infection was 8 years old, with a range from 8 days to 14 years old except that B/Taiwan/3807/06, B/Taiwan/3842/06, B/Taiwan/1575/07 and B/Taiwan/1540/07 were 19, 18, 23 and 43 years old respectively. Seventy-four patients are male and seventy-one are female. To study the hemagglutinin inhibition titers for the influenza virus $\mathrm{B}$ isolates, five adult volunteers including four normal individuals and one patient (P139) with impaired immune function were recruited to receive vaccines containing $\mathrm{A} / \mathrm{New}$ Caledonia/20/99, A/Wisconsin/67/05 and B/Malaysia/2506/04 strains. Informed consent was obtained from all participants. Patient P139 described that he was incapable of generating anti-hepatitis B virus (HBV) surface antibodies after repeatedly inoculated with HBV vaccine. Serum samples were collected prior to and 3 months after vaccination.

\section{Virus Isolation and Confirmation}

Filtrates from transport medium containing throat swabs were inoculated into Madin-Darby Canine Kidney (MDCK) cells. HA tests with guinea pig red blood cells were used to test the cultural supernatant for influenza B viral infection. Infected cells were detected using an IMAGEN $^{\mathrm{TM}}$ influenza virus test kits (DaKo Cytomation Ltd, Cambs, UK) contain fluorescein isothiocyanate(FITC) conjugated monoclonal antibodies which bind specifically to influenza virus type $B$.

\section{RNA Extraction and RT-PCR}

Viral RNA was extracted from $140 \mu \mathrm{L}$ of infected tissue culture fluid using a QIAamp Viral RNA mini Kit (QIAGEN Inc., CA). Real-time PCR was performed with $5 \mu \mathrm{L}$ RNA, Taqman one-step RT-PCR master mix reagents (Roche, New Jersey USA), $400 \mathrm{nM}$ primer and $100 \mathrm{nM}$ probe. The primers and probe used were according to Garbino et al. [20] and the cycling condition is $30 \mathrm{~min}$ at $48^{\circ} \mathrm{C}, 10 \mathrm{~min}$ at $95^{\circ} \mathrm{C}$, and 40 cycles of 15 seconds at $95^{\circ} \mathrm{C}$ and $1 \mathrm{~min}$ at $60^{\circ} \mathrm{C}$. In addition, $5 \mu \mathrm{L}$ of eluted RNA were used for amplification with a QIAGEN one-step reverse transcription (RT)-PCR reagent. RT-PCR and sequencing for HA and NA were performed according to Tsai et al. [19].

\section{Nucleotide Sequence Analysis}

DNA sequence analysis was performed using software from the Wisconsin Genetics Computer Group (GCG) $[19,21,22]$. All nucleotide sequences identified in this study have been deposited in GenBank (accession numbers EU234376 to EU234451).

\section{Phylogenetic Analysis}

Alignment of the respective 739 and 251 base pairs of HA and NA gene sequences was performed using the DNASTAR MegAlign clustal method. Phylogenetic trees were constructed using the neighbor-joining method based on Kimura's 2-parameter distance matrix with 1000 bootstrap replicates, using the MEGA (version 3.0) and PHYLIP (version 3.6) software packages [23-25]. We used MEGA for construction of neighbor-joining trees and PHYLIP for parsimony and maximum-likelihood meth- 


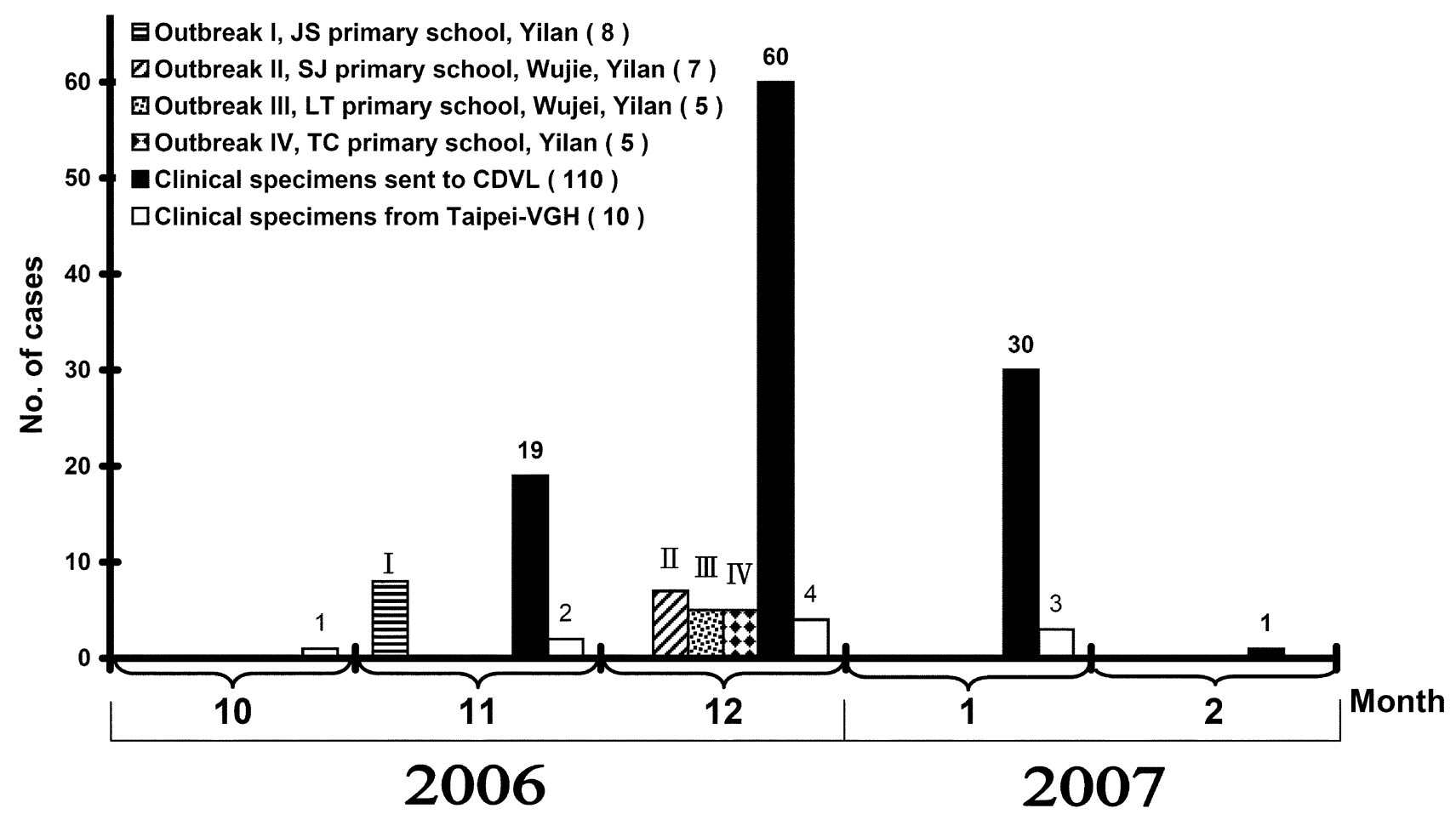

Figure I

Data on influenza B virus outbreak in North Taiwan between October 2006 and February 2007. Of 452 clinical respiratory samples examined, I 45 (32\%) tested positive for a B/Malaysia/2506/04-like strain (B reassortant lineage). The data came from 4 outbreaks and 2 group samples: Outbreak I, 8 patients from Yilan, Jiaosi (YLJS); outbreak II, 7 patients from ShaiJin, Yilan, Wujie (YLWJ-SJ); outbreak III, 5 patients from Li-Tse, Yilan, Wujie (YLWJ-LT); outbreak IV, 5 patients from Yilan, Toucheng (YLTC); group I, I I0 patients from other clinics of CDVL; group 2, I0 patients from Taipei-VGH ordinary clinic.

ods to verify the topology of taxas shown in the trees. In this study, all trees are shown as the neighbor-joining tree from MEGA.

\section{Hemagglutinin Inhibition Test}

HI testing of 2006-2007 samples was performed using the World Health Organization (WHO) Influenza Reagent Kit for identifying influenza isolates, produced and distributed by WHO collaborating center for surveillance, epidemiology and control of influenza in American Continent (CDC, USA) as described in the kit's manual. Reference strain samples consisted of distinct influenza B antisera from four epidemics: B/Malaysia/2506/04 (B reassortant lineage), B/Hong Kong/330/01 (Victoria lineage), B/ shanghai/361/02 (Yamagata lineage), and B/Sichuan/ 379/99 (Yamagata lineage).

\section{Results}

Reassortant Influenza B Virus Epidemiology

Among HA screening tests positive cases from 452 specimens, $145(32 \%)$ were confirmed to have influenza B infection using both real-time PCR and IFA test. The epi- demiological curve and geographic distribution analyses demonstrated that the influenza $\mathrm{B}$ infection reach the peak in December 2006 and there were four outbreaks in Yilan county located in the northern region of Taiwan: outbreak I, 8 children from Jiaosi town; outbreak II, 7 students from Shai-Jin Elementary School in Wujie town; outbreak III, 5 students from Li-Tse Elementary School in Wujie town; and outbreak IV, 5 children from Toucheng town (Figures 1 and 2). Major symptoms included vomit, rhinorrhea, myalgia, diarrhea, prostration, lethargy, pharynegeal vesicles or ulcers, cough, sore throat, headache, and fever (temperature $>38^{\circ} \mathrm{C}$ ), with a duration of 1-2 weeks. Of the patients from Yilan county, all 25 were in kindergarten or primary school, aged between 6 and 8 years old.

\section{Phylogenetic Analysis}

According to results obtained from phylogenetic analyses of nearly full-length HA nucleotide sequences for the HA1 subunit (1100 nt) of influenza B virus isolates from 39 patients including 38 children and 1 adult (B/Taiwan/ 3842/06), all isolates clustered with B/Malaysia/2506/04- 


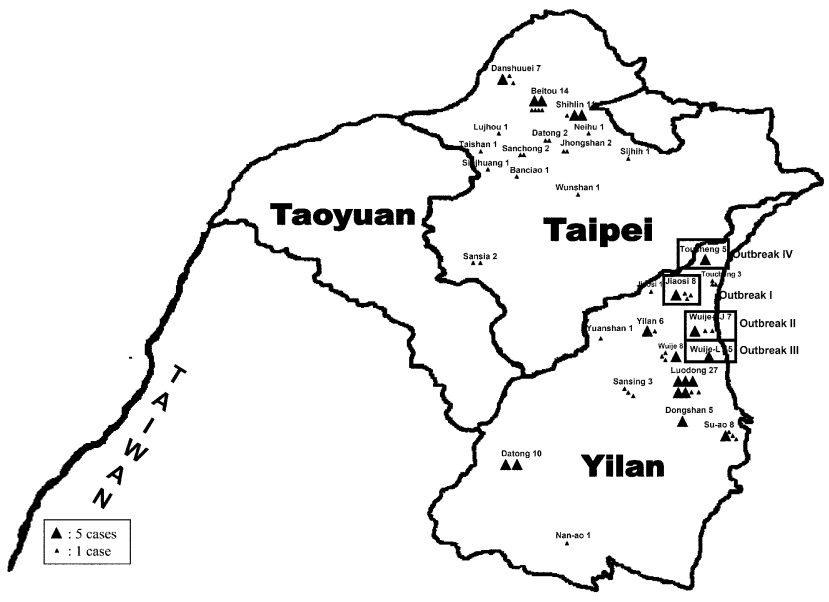

Figure 2 Approximate distribution of influenza B viruses analyzed for this research.

HA with a bootstrap value of $96(\mathrm{P}<0.01)$ (Figure 3$)$. B/ Malaysia/2506/04 has been identified by the WHO as the primary vaccine strain for the 2006-2007 flu season in the northern hemisphere. Note that 4 variants (cluster I) in outbreak II clustered on a single branch with a bootstrap value of 79 and statistical p value $<0.01$ (Figure 3 ). In terms of NA genes, all 37 Taiwanese isolates were identified as belonging to the $\mathrm{B}$ reassortant lineage $(\mathrm{P}<0.05)$ except two isolates were not PCR amplified (Figure 4).

\section{Variation in HA and NA Amino Acid Sequences}

Compared to amino acid residues 22-234 of the B/Malaysia/2506/04 HA protein, most of the Taiwanese isolates had only 2-3 changes. Exceptions included 1 strain from outbreak I (B/Taiwan/3009/06, 9 amino acid changes) and 4 variants (cluster I) from outbreak II (B/Taiwan/ 3802/06, B/Taiwan/3804/06, B/Taiwan/3805/06, and B/ Taiwan/3790/06, with a combined total of 14 amino acid changes) (Table 1$)$. Conserved region results indicate that amino acid residues $16-77$ of the B/Malaysia/2506/04 NA protein originated in the previous season's Yamagata lineage strain (data not shown).

\section{HI Titers}

We used a panel of 4 reference sheep antisera to test the HI titers of 10 influenza $\mathrm{B}$ isolates; results are presented in Table 2. The HI titers of the B/Malaysia/2506/04-sheep antiserum to the Taiwanese influenza virus $\mathrm{B}$ strains belonged to outbreaks III, IV and the sporadic influenza B cases ranged from 1,280 to 2,560 . In contrast, only 640 to 1,280 HI titers of the B/Malaysia/2506/04-sheep antiserum were identified as belonging to outbreak II. The number of HI titers for the B/Hong Kong/330/01-sheep antiserum ranged from 160 to 640 . The smallest numbers of HI titers were observed in the antisera against the two virus isolates belonging to the Yamagata lineage.

\section{Post-Vaccination Serum Antibody Responses}

Pre- and post-immunized serum samples were collected from 5 volunteers who had received the influenza vaccine for purposes of evaluating HI titers; all 5 generated antibody titers between 160 and 640 to the virus variants in outbreak II (Table 3). Of those 5, 3 showed 4 to 8 -fold increases in $\mathrm{HI}$ antibody titers. The seroconversion factor was 1 for the patient diagnosed as immunologically incompetent. Another patient who reported to have received very few influenza vaccinations in the preceding ten years had exceptionally low antibody titers in his preimmunized serum but an acceptable number following immunization.

\section{Discussion}

At least three distinct variants of influenza B virus with origins in China have been collected from Taiwanese patients since 2002: B/Shanghai/361/2002-like (Yamagata lineage), B/Hong Kong/330/01-like (Victoria lineage), and B/Hong Kong/1351/02-like (B reassortant with Victoria-like $\mathrm{HA}$ and Yamagata-like NA genes) $[19,21,22]$. We characterized influenza viruses isolated form both children and adults living in north Taiwan between October 2006 and February 2007 for purposes of analyzing the antigenic properties and phylogenetic relationships of HA and NA genes from the influenza B virus isolates. Our results suggest the increasing reappearance of the VIC-HA/YAM-NA reassortant influenza B viruses during this period, with most outbreaks affecting children aged 6 to 8 years (Figures 1 and 2).

A total of 39 clinical isolates of reassortant influenza B viruses were used for molecular evolutionary analyses of HA and NA genes. Our results show that the HA genes belonged to the $\mathrm{B} /$ Victoria/2/87 lineage (Figure 3 ). We also found evidence of four outbreaks of reassortant influenza $\mathrm{B}$ viruses in the $\mathrm{B} /$ Victoria/2/87 lineage among elementary school-aged children living in Taiwan's Yilan County. Note the 4 variants (cluster I) in outbreak II that are clustered on a single branch in Figure 2-supported by a bootstrap value of $79 \%$. The statistical $P$-value $(P<0.01)$ indicate the cluster strains for significance. These viruses were genetically similar to the B/Malaysia/2506/04 vaccine strain that was recommended as the vaccine candidate for the 2006-2007 flu season in the northern hemisphere. Results from sequence analyses of NA genes from the 37 Taiwan isolates indicate that they all belonged to the $\mathrm{B} /$ Yamagata/16/88 lineage (Figure 4)that is, they clustered with two strains belonging to the $\mathrm{B}$ reassortant lineage, the $\mathrm{B} / \mathrm{Malaysia} / 2506 / 04$ vaccine strain and B/Hong Kong/1351/02. 


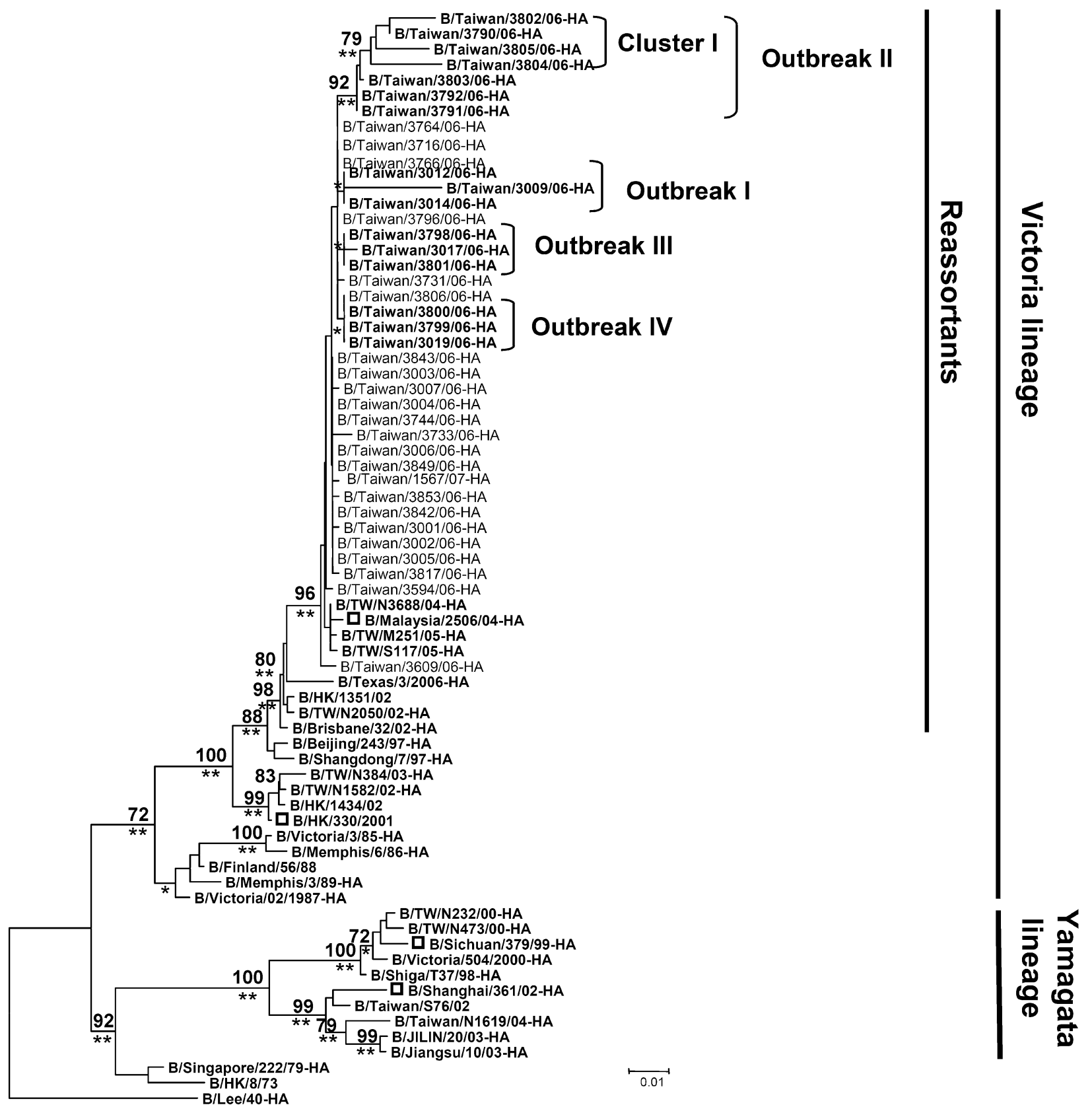

Figure 3

A phylogenetic analysis of HA genes from influenza B virus isolates obtained between October 2006 and February 2007. Dendrogram of 39 influenza $B$ strains and 32 GenBank reference strains is based on 739 nucleotides $(75$ to 813$)$ of the HAI gene (neighbor-joining method with DNASTAR distance measure program; MEGA, Version 3.0). The linear unrooted phylogenetic dendrograms present the $B / L e e / 40$ sequence as an outgroup. Branch length indicates genetic distance according to indicated distance scale $(0.01$, I\% difference). Bootstrap analysis percentages $(n=1000)$ for each branch are indicated. The statistical $\mathrm{p}$-values were labeled on each node $(* \mathrm{P}<0.05$ and $* * \mathrm{P}<0.0 \mathrm{I})$. 


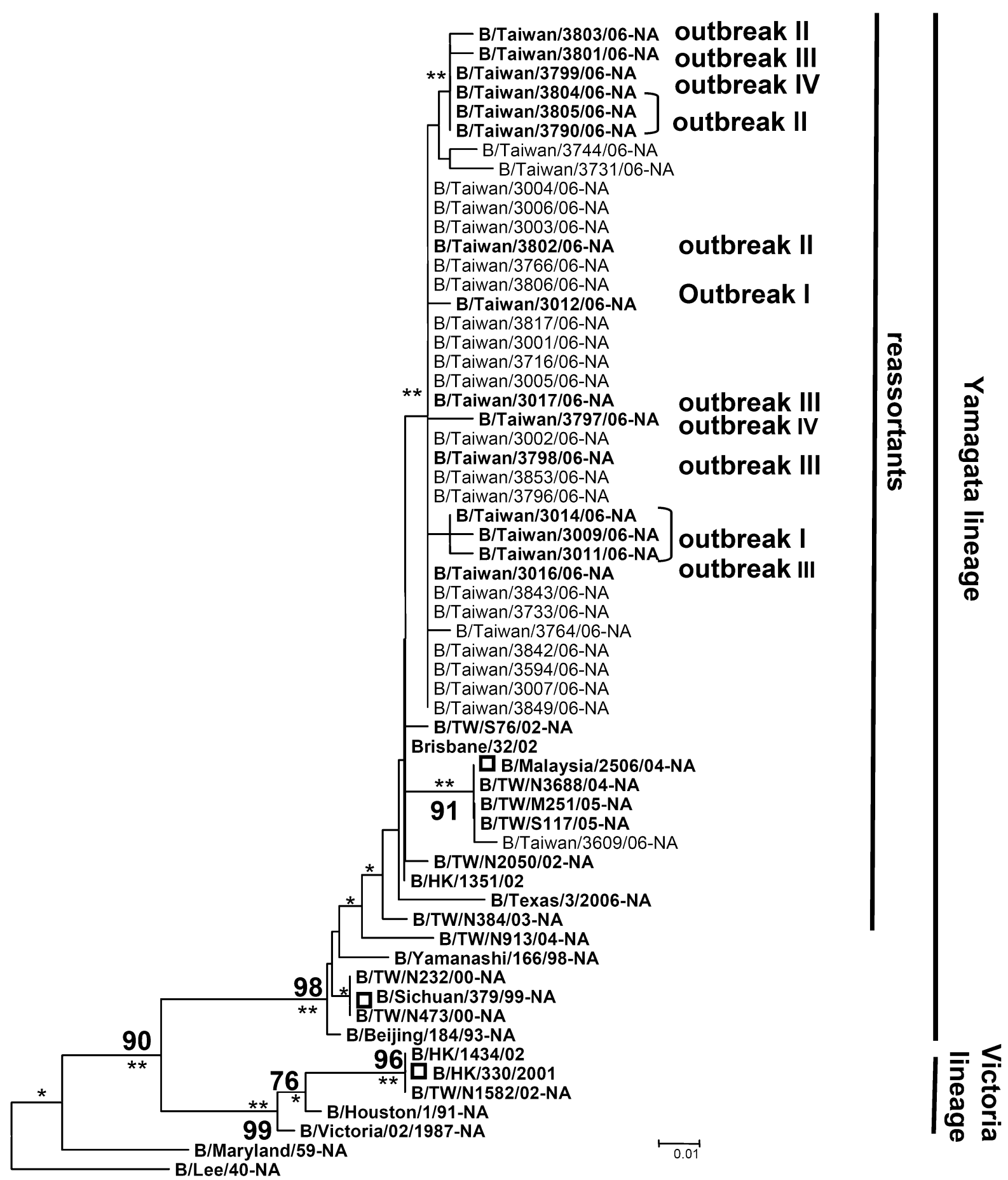

Figure 4

Phylogenetic analysis of NA genes from influenza B virus isolates obtained between October 2006 and February 2007. Dendrogram of 37 influenza $B$ strains and 23 GenBank reference strains is based on 25 I nucleotides (33 to 283) of the NA gene (neighbor-joining method with DNASTAR distance measure program; MEGA, Version 3.0). The linear unrooted phylogenetic dendrograms present the $\mathrm{B} / \mathrm{Lee} / 40$ sequence as an outgroup. Branch length indicates genetic distance according to indicated distance scale $(0.01,1 \%$ difference). Bootstrap analysis percentages $(n=1000)$ for each branch are indicated. The statistical $\mathrm{P}$-values were labeled on each node $(* \mathrm{P}<0.05$ and $* * \mathrm{P}<0.0 \mathrm{I})$. 
Table I: Variations in HA amino acid sequence in recent influenza B viruses of Victoria lineage in Taiwan during 2006.10-2007.02 influenza season.

\begin{tabular}{|c|c|c|c|c|c|c|c|c|c|c|c|c|c|c|c|c|c|c|c|c|c|c|c|c|c|c|c|c|c|c|c|c|c|c|}
\hline & & \multicolumn{33}{|c|}{ Amino acid position } \\
\hline Outbreak & $\begin{array}{c}\text { Virus } \\
\text { strain(s) }\end{array}$ & $\begin{array}{l}2 \\
4\end{array}$ & $\begin{array}{l}2 \\
5\end{array}$ & $\begin{array}{l}4 \\
8\end{array}$ & $\begin{array}{l}4 \\
9\end{array}$ & $\begin{array}{l}7 \\
9\end{array}$ & $\begin{array}{l}8 \\
0\end{array}$ & $\begin{array}{l}8 \\
3\end{array}$ & $\begin{array}{l}1 \\
0 \\
0\end{array}$ & $\begin{array}{l}1 \\
1 \\
6\end{array}$ & $\begin{array}{l}1 \\
2 \\
1\end{array}$ & $\begin{array}{l}1 \\
2 \\
7\end{array}$ & $\begin{array}{l}1 \\
2 \\
8\end{array}$ & $\begin{array}{l}1 \\
2 \\
9\end{array}$ & $\begin{array}{l}1 \\
3 \\
4\end{array}$ & $\begin{array}{l}1 \\
3 \\
5\end{array}$ & $\begin{array}{l}1 \\
4 \\
6\end{array}$ & $\begin{array}{l}1 \\
5 \\
4\end{array}$ & $\begin{array}{l}1 \\
6 \\
4\end{array}$ & $\begin{array}{l}1 \\
7 \\
6\end{array}$ & $\begin{array}{l}1 \\
8 \\
2\end{array}$ & $\begin{array}{l}1 \\
8 \\
6\end{array}$ & $\begin{array}{l}1 \\
8 \\
9\end{array}$ & $\begin{array}{l}1 \\
9 \\
7\end{array}$ & $\begin{array}{l}1 \\
9 \\
9\end{array}$ & $\begin{array}{l}2 \\
0 \\
4\end{array}$ & $\begin{array}{l}2 \\
1 \\
4\end{array}$ & $\begin{array}{l}2 \\
1 \\
6\end{array}$ & $\begin{array}{l}2 \\
1 \\
7\end{array}$ & $\begin{array}{l}2 \\
1 \\
8\end{array}$ & $\begin{array}{l}2 \\
2 \\
0\end{array}$ & $\begin{array}{l}2 \\
2 \\
1\end{array}$ & $\begin{array}{l}2 \\
2 \\
8\end{array}$ & $\begin{array}{l}2 \\
3 \\
0\end{array}$ \\
\hline \multirow[t]{8}{*}{$\begin{array}{l}\text { Reference } \\
\text { strains }\end{array}$} & $\begin{array}{c}\text { B/Malaysia/ } \\
2506 / 04\end{array}$ & $\mathrm{v}$ & $\mathrm{N}$ & E & $T$ & $A$ & $\mathrm{R}$ & $R$ & $\mathrm{D}$ & $\mathrm{H}$ & $\mathrm{T}$ & $A$ & $\mathrm{E}$ & $\mathrm{N}$ & S & $Y$ & v & A & $\mathrm{D}$ & $\mathrm{E}$ & $T$ & $\mathrm{D}$ & $T$ & $N$ & A & $\mathrm{L}$ & $T$ & $\mathrm{~s}$ & $A$ & $\mathrm{~N}$ & $\mathrm{v}$ & $\mathrm{T}$ & 1 & G \\
\hline & $\begin{array}{l}\text { B/Beijing/ } \\
\text { 243/97 }\end{array}$ & & & $\mathrm{K}$ & & & $\mathrm{K}$ & & & & 1 & & & $\mathrm{~K}$ & $P$ & & & V & & & & & & $\mathrm{T}$ & $\mathrm{T}$ & & & & & & & & & \\
\hline & $\begin{array}{c}\mathrm{B} / \mathrm{HK} / 330 / \\
200 \mathrm{I}\end{array}$ & & & $\mathrm{K}$ & & & K & & & $\mathrm{R}$ & $\mathrm{N}$ & & & $\mathrm{K}$ & $P$ & & & & $\mathrm{E}$ & & & & & $\mathrm{s}$ & $\mathrm{T}$ & & & & & & & & & \\
\hline & $\begin{array}{c}\text { B/TW/ } \\
\text { N1582/02 }\end{array}$ & & & $\mathrm{K}$ & & & $\mathrm{K}$ & & & $\mathrm{R}$ & $N$ & & & $\mathrm{E}$ & $P$ & & & & $\mathrm{E}$ & & & & & & $\mathrm{T}$ & & & & & & & & & \\
\hline & $\begin{array}{c}\text { B/TW/ } \\
\text { N384/03 }\end{array}$ & & & $\mathrm{K}$ & & & $\mathrm{K}$ & & & $\mathrm{R}$ & $N$ & & & $\mathrm{E}$ & $P$ & & 1 & & $\mathrm{E}$ & & & & & & $\mathrm{T}$ & & & & & & & & & \\
\hline & $\begin{array}{c}\text { B/TW/ } \\
\text { N3688/04 }\end{array}$ & & & & & & & & & & & & & & $P$ & & & & & & & & & & $\mathrm{~T}$ & & & & & & & & & \\
\hline & $\begin{array}{c}\text { B/TW/ } \\
\text { M251/05 }\end{array}$ & & & & & & & & & & & $\mathrm{V}$ & & & $P$ & & & & & & & & & & $\mathrm{~T}$ & & & & & & & & & \\
\hline & $\begin{array}{l}\text { B/TW/ } \\
\text { S1I7/05 }\end{array}$ & $\mathrm{L}$ & & & & & & & & & & & & & $P$ & & & & & & & & & & $\mathrm{~T}$ & & & & & & & & & \\
\hline \multirow[t]{3}{*}{1} & $\begin{array}{c}\text { B/Taiwan/ } \\
3009 / 06\end{array}$ & & & & $A$ & $P$ & & & $\mathrm{H}$ & & & & $\mathrm{K}$ & & $P$ & $\mathrm{H}$ & & & & $\mathrm{K}$ & & & & $\mathrm{T}$ & $T$ & & & & & & & & & \\
\hline & $\begin{array}{c}\text { B/Taiwan/ } \\
3012 / 06\end{array}$ & & & & & & & & & & & & & & $P$ & & & & & & & & & & $\mathrm{~T}$ & & & & & & & & & \\
\hline & $\begin{array}{c}\text { B/Taiwan/ } \\
30 \mid 4 / 06\end{array}$ & & & & & & & & & & & & & & $P$ & & & & & & & & & & $\mathrm{~T}$ & & & & & & & & & \\
\hline \multirow[t]{7}{*}{ II } & $\begin{array}{c}\text { B/Taiwan/ } \\
3802 / 06\end{array}$ & & & & & & & & & & & & & & $P$ & & & & & & $P$ & $Y$ & $A$ & & $\mathrm{~T}$ & $\mathrm{~F}$ & & & $\mathrm{v}$ & & & & & $\mathrm{v}$ \\
\hline & $\begin{array}{c}\text { B/Taiwan/ } \\
3804 / 06\end{array}$ & & & & & & & & & & & & & & $P$ & & & & & & & & & & $\mathrm{~T}$ & & & & & & & G & $\mathrm{T}$ & v \\
\hline & $\begin{array}{c}\text { B/Taiwan/ } \\
3805 / 06\end{array}$ & & & & & & & & & & & & & & $P$ & & & & & & $P$ & & & & $\mathrm{~T}$ & $\mathrm{~F}$ & A & & & & $\mathrm{K}$ & $A$ & & v \\
\hline & $\begin{array}{c}\text { B/Taiwan/ } \\
3790 / 06\end{array}$ & & & & & & & & & & & & & & $P$ & & & & & & $P$ & & & & $\mathrm{~T}$ & $\mathrm{~F}$ & & $Y$ & & & & & & v \\
\hline & $\begin{array}{c}\text { B/Taiwan/ } \\
3803 / 06\end{array}$ & & & & & & & & & & & & & & $P$ & & & & & & & & & & $\mathrm{~T}$ & & & & & & & & & \\
\hline & $\begin{array}{c}\text { B/Taiwan/ } \\
3791 / 06\end{array}$ & & & & & & & & & & & & & & $P$ & & & & & & & & & & $\mathrm{~T}$ & & & & & & & & & \\
\hline & $\begin{array}{c}\text { B/Taiwan/ } \\
3792 / 06\end{array}$ & & & & & & & & & & & & & & $P$ & & & & & & & & & & $\mathrm{~T}$ & & & & & & & & & \\
\hline \multirow[t]{3}{*}{ III } & $\begin{array}{c}\text { B/Taiwan/ } \\
3017 / 06\end{array}$ & & $Y$ & & & & & & & & & & & & $P$ & & & & & & & & & & $T$ & & & & & & & & & \\
\hline & $\begin{array}{c}\text { B/Taiwan/ } \\
3798 / 06\end{array}$ & & & & & & & & & & & & & & $P$ & & & & & & & & & & $\mathrm{~T}$ & & & & & & & & & \\
\hline & $\begin{array}{c}\text { B/Taiwan/ } \\
3801 / 06\end{array}$ & & & & & & & & & & & & & & $P$ & & & & & & & & & & $\mathrm{~T}$ & & & & & & & & & \\
\hline
\end{tabular}


Table I: Variations in HA amino acid sequence in recent influenza B viruses of Victoria lineage in Taiwan during 2006.10-2007.02 influenza season. (Continued)

\begin{tabular}{|c|c|c|c|c|c|c|}
\hline \multirow[t]{3}{*}{ IV } & $\begin{array}{c}\text { B/Taiwan/ } \\
3799 / 06\end{array}$ & & $P$ & & $\mathrm{~T}$ & $\mathrm{~S}$ \\
\hline & $\begin{array}{c}\text { B/Taiwan/ } \\
3800 / 06\end{array}$ & & $P$ & & $\mathrm{~T}$ & $S$ \\
\hline & $\begin{array}{c}\text { B/Taiwan/ } \\
3019 / 06\end{array}$ & & $P$ & & $\mathrm{~T}$ & $S$ \\
\hline \multirow[t]{7}{*}{ sporadic } & $\begin{array}{l}\text { B/Taiwan/ } \\
\text { 3594/06* }\end{array}$ & & $P$ & & $T$ & \\
\hline & $\begin{array}{c}\text { B/Taiwan/ } \\
3609 / 06\end{array}$ & A & $P$ & & $\mathrm{~T}$ & \\
\hline & $\begin{array}{c}\text { B/Taiwan/ } \\
3733 / 06\end{array}$ & & $P$ & S & $T$ & \\
\hline & $\begin{array}{c}\text { B/Taiwan/ } \\
3806 / 06\end{array}$ & & $P$ & & $T$ & S \\
\hline & $\begin{array}{c}\text { B/Taiwan/ } \\
3853 / 06\end{array}$ & & $P$ & & $\mathrm{~T}$ & D \\
\hline & $\begin{array}{c}\text { B/Taiwan/ } \\
3001 / 06\end{array}$ & 1 & & & & \\
\hline & $\begin{array}{l}\text { B/Taiwan/ } \\
3007 / 06\end{array}$ & & $P$ & & $\mathrm{~T}$ & M \\
\hline
\end{tabular}
*: Sporadic variant strain the same as II isolates including B/Taiwan/37/6/06, B/Taiwan/3744/06, B/Taiwan/373I/06, B/Taiwan/3764/06, B/Taiwan/3766/06, B/Taiwan/3796/06, B/Taiwan/3817/06, B/Taiwan/3842/06, B/Taiwan/3843/ 
Table 2: Antigenic virus identification of different Influenza B viruses.

\begin{tabular}{|c|c|c|c|c|c|}
\hline \multirow[b]{2}{*}{ Outbreak } & \multirow[b]{2}{*}{ Patient ID Number } & \multicolumn{4}{|c|}{ HI Antigen Typing (titer) } \\
\hline & & B/Malaysia/2506/04a & B/Hong Kong/330/0 $\mathrm{I}^{\mathrm{b}}$ & $\mathrm{B} /$ Shanghai/36I/02c & B/Sichuan/379/99c \\
\hline \multirow[t]{3}{*}{ II } & B/Taiwan/3802/06 & 640 & 320 & 10 & 10 \\
\hline & B/Taiwan/3803/06 & 640 & 160 & 10 & 10 \\
\hline & B/Taiwan/3805/06 & 1280 & 320 & 10 & 10 \\
\hline III & B/Taiwan/3798/06 & 1280 & 320 & 10 & 10 \\
\hline IV & B/Taiwan/3799/06 & 2560 & 320 & 10 & 10 \\
\hline \multirow[t]{9}{*}{ Sporadic } & B/Taiwan/3853/06 & 1280 & 320 & 10 & 10 \\
\hline & B/Taiwan/37I6/06 & 1280 & 160 & 10 & 10 \\
\hline & B/Taiwan/3733/06 & 2560 & 640 & 10 & 10 \\
\hline & B/Taiwan/3594/06 & 2560 & 640 & 10 & 10 \\
\hline & B/Taiwan/300I/06 & 2560 & 320 & 10 & 10 \\
\hline & B/Malaysia/2506/04a & 320 & & & \\
\hline & B/Hong Kong $/ 330 / 0 \mathrm{I}^{\mathrm{b}}$ & & 160 & & \\
\hline & B/Shanghai/36I/02c & & & 1280 & \\
\hline & B/Sichuan/379/99c & & & & 160 \\
\hline
\end{tabular}

aB reassortant lineage

bVictoria lineage

cYamagata lineage

Compared to amino acid residues $22-234$ of the B/Malaysia/2506/04 HA protein, most of the Taiwanese isolates had only 2-3 changes. Exceptions included 1 strain from outbreak I with 9 changes and 4 variants (cluster I) from outbreak II with 14 changes (Table 1). Genetic variation in this highly variant region suggests a potential for these reassortant variants to cause future outbreaks.
We performed HI tests for the identification of HA in circulating influenza $\mathrm{B}$ viruses. Our results show that the majority of circulating influenza B viruses (i.e., B/Malaysia/2506/04-like viruses) collected between October 2006 to and February 2007 belonged to the B/Victoria/2/87 lineage (Table 2). The data also indicate that the lowest HA titers were observed with sheep antisera against the other

Table 3: Comparison of Antibody Results and Seroconversion Factor for Reassortant Influenza B Viruses

\begin{tabular}{|c|c|c|c|c|c|c|c|c|c|c|c|c|c|c|c|c|c|}
\hline \multirow{3}{*}{ Outbreak } & \multirow{3}{*}{ Patient ID Number } & \multicolumn{11}{|c|}{ HI antibody results (titer) } & \multirow{2}{*}{\multicolumn{5}{|c|}{ Seroconversion factorc }} \\
\hline & & \multicolumn{2}{|c|}{ P004 } & \multicolumn{2}{|c|}{ P009 } & \multicolumn{2}{|c|}{ PI09 } & \multicolumn{2}{|c|}{$\mathrm{PI} 39$} & \multicolumn{2}{|c|}{$\mathrm{P} \mid 82$} & \multirow[t]{2}{*}{$P C^{b}$} & & & & & \\
\hline & & pred $^{d}$ & poste & pre & post & pre & post & pre & post & pre & post & & P004 & P009 & PI09 & $\mathrm{PI} 39$ & $\mathrm{P} \mid 82$ \\
\hline II & B/Taiwan/3802/06 & 80 & 320 & 80 & 640 & 40 & 160 & 160 & 160 & 10 & 640 & 2560 & 4 & 8 & 4 & 1 & 64 \\
\hline (Cluster I) & B/Taiwan/3805/06 & 80 & 320 & 80 & 640 & 80 & 160 & 160 & 160 & 10 & 640 & 2560 & 4 & 8 & 2 & I & 64 \\
\hline \multirow[t]{2}{*}{ III } & B/Taiwan/3798/06 & 20 & 160 & 40 & 160 & 20 & 80 & 40 & 40 & 10 & 160 & 1280 & 8 & 4 & 4 & I & 16 \\
\hline & B/Taiwan/3594/06 & 40 & 320 & 40 & 320 & 40 & 320 & 80 & 80 & 10 & 160 & 5120 & 8 & 8 & 8 & 1 & 16 \\
\hline \multirow[t]{3}{*}{ sporadic } & B/Taiwan/3853/06 & 20 & 160 & 80 & 160 & 40 & 160 & 80 & 80 & 10 & 160 & 1280 & 8 & 2 & 4 & 1 & 16 \\
\hline & B/Taiwan/300I/06 & 20 & 160 & 40 & 320 & 20 & 80 & 40 & 40 & $<10$ & 80 & 2560 & 8 & 8 & 4 & 1 & 8 \\
\hline & PCa (B/Malaysia) & 40 & 160 & 80 & 160 & 20 & 80 & 40 & 40 & 10 & 80 & 640 & 4 & 2 & 4 & I & 8 \\
\hline
\end{tabular}

aPositive control (B/Malaysia/2506/04) antigen (CDC, Atlanta, USA).

bPositive control (B/Malaysia/2506/04) reference sheep antiserum (CDC, Atlanta, USA).

cSeroconversion factor represents the number of fold-increase in Serum HI titer post-vaccination.

dPre-immune.

ePost-immune. 
two isolates belonging to the Yamagata lineage. We used a panel of serum samples from 5 patients who received influenza vaccinations to test their ability to generate protective immunity against influenza $\mathrm{B}$ variants isolated from young children living in Yilan county, using seroconversion factor as our criteria. Of the 5 patients, 4 showed a minimum of 4 -fold increases in $\mathrm{HI}$ titers postvaccination; the seroconversion factor was 1 for the fifth patient, who was later diagnosed as immunologically incompetent (Table 3). These results suggest that the current influenza vaccine is still effective in stimulating protective immunity against the influenza $B$ variants that we isolated [26-28]. Previously, Jian et al. reported a group of influenza B viruses isolated in Taiwan during the 20042005 and 2006-2007 epidemics [29]. In this study, we identified a group of children, lived in the northern regions of Taiwan, infected with influenza $B$ virus variant. Most of them had severe headache symptoms when they had the virus infection. This has not been found by Jian et al. In addition, we have performed "hemagglutinin inhibition (HI) test" in our study (Table 2 and 3) which have never been reported by Jian et al.

The gene variable analysis of influenza viruses can provide information for epidemic and pandemic outbreak surveillance and determination of vaccine strain selection. In this study, we have shown data suggesting that the contemporary vaccine was still effective in stimulating protective immunity against the influenza $\mathrm{B}$ variants that we isolated. Therefore, continuous monitoring of emerging influenza B virus variants is vital to successful control not only locally, but also internationally.

\section{Competing interests}

The authors declare that they have no competing interests.

\section{Authors' contributions}

LYM performed the analysis of the data and drafted the manuscript. WSF and LCM revised the manuscript and did supplementary analysis. CKH, CYJ and LWT participated in the design of the study. CYMA participated in the design, revised the manuscript and coordination of the study. They all approved the final version of the manuscript.

\section{Acknowledgements}

This study was supported in part by grants from the Republic of China (ROC) National Science Council (no. NSC 97-232I-B-010-003), the ROC Centers for Disease Control (no. CDC-96-RD-003), and the Ministry of Education, Aim for the Top University Plan. We thank staffs from the Genome Research Center at National Yang-Ming University for their technical support. We also thank colleagues at the AIDS Prevention and Research Center of National Yang-Ming University and Division of Clinical Virology, Department of Pathology and Laboratory Medicine, of Taipei Veterans General Hospital for helpful discussions and support.

\section{References}

I. Haaheim LR, Pattison JR, Whitley RJ: Influenzaviruses. In A practical guide to Clinical Virology 2nd edition. Edited by: Haaheim LR. Oxford, England: John Wiley \& Sons Ltd; 2002:67-74.

2. Murray PR, Rosenthal KS, Kobayashi GS, Pfaller MA: Orthomyxoviruses: Medical Microbiology. 5th edition. Philadelphia, PA, USA:ELSEVIER MOSBY; 2005:609-617.

3. Balicer RD, Huerta M, Levy Y, Davidovitch N, Grotto I: Influenza outbreak control in confined settings. Emerg Infect Dis 2005, I I:579-583.

4. Bhat N, Wright JG, Broder KR, Murray EL, Greenberg ME, Glover MJ, Likos AM, Posey DL, Klimov A, Lindstrom SE, Balish A, Medina MJ, Wallis TR, Guarner J, Paddock CD, Shieh WJ, Zaki SR, Sejvar J], Shay DK, Harper SA, Cox NJ, Fukuda K, Uyeki TM: Influenza-associated deaths among children in the United States, 2003-2004. N Engl J Med 2005, 353:2559-2567.

5. Bosis S, Esposito S, Niesters HGM, Zuccotti GV, Marseglia G, Lanari M, Zuin G, Pelucchi C, Osterhaus ADME, Principi N: Role of respiratory pathogens in infants hospitalized for a first episode of wheezing and their impact on recurrences. Clin Microbiol Infect 2008, 14:677-684.

6. Knipe DM, Howley PM, Griffin DE, Lamb RA, Martin MA, Roizman B, Strauss E: Orthomyxoviridae: The Viruses and their replication. In Fields Virology 5th edition. Edited by: Palese P, Shaw ML. Philadelphia, PA, USA: LIPPINCOTT WILLIAMS \& WILKINS; 2007:1647-1689.

7. Weitzel T, Schnabel E, Dieckmann S, Borner U, Schweiger B: Evaluation of a new point-of-care test for influenza $A$ and $B$ virus in travelers with influenza-like symptoms. Clin Microbiol Infect 2007, I 3:665-669.

8. Nerome R, Hiromoto $Y$, Sugita S, Tanabe N, Ishida M, Matsumoto M, Lindstrom SE, Takahashi T, Nerome K: Evolutionary characteristics of influenza $B$ virus since its first isolation in 1940: dynamic circulation of deletion and insertion mechanism. Arch Virol 1998, I43:I569-I583.

9. McCullers JA, Wang GC, He S, Webster RG: Reassortment and insertion-deletion are strategies for the evolution of influenza B viruses in nature. J Virol 1999, 73:7343-7348.

10. Xu X, Lindstrom SE, Shaw MW, Smith CB, Hall HE, Mungall BA, Subbarao K, Cox NJ, Klimov A: Reassortment and evolution of current human influenza A and B viruses. Virus Res 2004, 1 03:55-60.

II. Rota PA, Wallis TR, Harmon MW, Rota JS, Kendal AP, Nerome K: Cocirculation of two distinct evolutionary lineages of influenza type B virus since 1983. Virology 1990, I 75:59-68.

12. Rota PA, Hemphill ML, Whistler T, Regnery HL, Kendal AP: Antigenic and genetic characterization of the haemagglutinins of recent cocirculating strains of influenza B virus. J Gen Virol 1992, 73(Pt 10):2737-2742.

13. Chi XS, Bolar TV, Zhao P, Rappaport R, Cheng SM: Cocirculation and evolution of two lineages of influenza $B$ viruses in europe and Israel in the 200I-2002 season. J Clin Microbiol 2003, 4I:5770-5773.

14. Ansaldi F, D'Agaro P, De FD, Puzelli S, Lin YP, Gregory V, Bennett M, Donatelli I, Gasparini R, Crovari P, Hay A, Campello C: Molecular characterization of influenza $B$ viruses circulating in northern Italy during the 200I-2002 epidemic season. J Med Virol 2003, 70:463-469.

15. Puzelli S, Frezza F, Fabiani C, Ansaldi F, Campitelli L, Lin YP, Gregory V, Bennett M, D'Agaro P, Campello C, Crovari P, Hay A, Donatelli I: Changes in the hemagglutinins and neuraminidases of human influenza B viruses isolated in Italy during the 200102, 2002-03, and 2003-04 seasons. J Med Virol 2004, 74:629-640.

16. Ansaldi F, Icardi G, Gasparini R, Campello C, Puzelli S, Bella A, Donatelli I, Salmaso S, Crovari P: New A/H3N2 influenza variant: a small genetic evolution but a heavy burden on the Italian population during the 2004-2005 season. J Clin Microbiol 2005, 43:3027-3029.

17. Motta FC, Siqueira MM, Lugon AK, Straliotto SM, Fernandes SB, Krawczuk MM: The reappearance of Victoria lineage influenza $B$ virus in Brazil, antigenic and molecular analysis. J Clin Virol 2006, 36:208-214.

18. Chen JM, Guo YJ, Wu KY, Guo JF, Wang M, Dong J, Zhang Y, Li Z, Shu $Y L$ : Exploration of the emergence of the Victoria lineage of influenza B virus. Arch Virol 2007, I 52:4I5-422. 
19. Tsai HP, Wang HC, Kiang D, Huang SW, Kuo PH, Liu CC, Su IJ, Wang JR: Increasing appearance of reassortant influenza $B$ virus in Taiwan from 2002 to 2005. J Clin Microbiol 2006, 44:2705-27I3.

20. Garbino J, Gerbase MW, Wunderli W, Deffernez C, Thomas Y, Rochat T, Ninet B, Schrenzel J, Yerly S, Perrin L, Soccal PM, Laurent $\mathrm{N}$, Kaiser $\mathrm{L}$ : Lower respiratory viral illnesses improved diagnosis by molecular methods and clinical impact. Am J Respir Crit Care Med 2004, 170: I 197-1203.

21. Lin JH, Chiu SC, Shaw MW, Lin YC, Lee CH, Chen HY, Klimov A: Characterization of the epidemic influenza $B$ viruses isolated during 2004-2005 season in Taiwan. Virus Res 2007, | 24:204-2|l.

22. Chen GW, Shih SR, Hsiao MR, Chang SC, Lin SH, Sun CF, Tsao KC: Multiple genotypes of influenza $B$ viruses cocirculated in Taiwan in 2004 and 2005. J Clin Microbiol 2007, 45: I5 I5-I522.

23. Kumar S, Tamura K, Nei M: MEGA3: integrated software for molecular evolutionary genetics analysis and sequence alignment. Brief Bioinform 2004, 5:150-163.

24. Hillis DM, Bull JJ: An empirical test of bootstrapping confidence in phylogenetic analysis. Syst Biol 1993, 42: 182-192.

25. Felsenstein J: PHYLIP-Phylogeny Inference Package (version 3.2). Cladistics 1989, 5:166.

26. Holm MV, Blank PR, Szucs TD: Trends in influenza vaccination coverage rates in Germany over five seasons from $200 \mathrm{I}$ to 2006. BMC Infect Dis 2007, 7:144-15I.

27. Madani TA, Ghabrah TM: Meningococcal, influenza virus, and hepatitis B virus vaccination coverage level among health care workers in Hajj. BMC Infect Dis 2007, 7:80-85.

28. Belshe RB, Newman FK, Cannon J, Duane C, Treanor J, Hoecke CV, Howe BJ, Dubin G: Serum antibody responses after intradermal vaccination against influenza. N ENGL J MED 2004, 35 I:2286-94.

29. Jian JW, Lai CT, Kuo CY, Kuo SHS, Hsu LC, Chen PJ, Wu HS, Liu MT: Genetic analysis and evaluation of the reassortment of influenza $B$ viruses isolated in Taiwan during the 2004-2005 and 2006-2007 epidemics. Virus research 2008, I3 I:243-249.

Publish with Bio Med Central and every scientist can read your work free of charge

"BioMed Central will be the most significant development for disseminating the results of biomedical research in our lifetime. "

Sir Paul Nurse, Cancer Research UK

Your research papers will be:

- available free of charge to the entire biomedical community

- peer reviewed and published immediately upon acceptance

- cited in PubMed and archived on PubMed Central

- yours - you keep the copyright

Submit your manuscript here:

http://www.biomedcentral.com/info/publishing_adv.asp
BioMedcentral 